\title{
IMPROVING OF THE NESTED PCR FOR DETECTION OF BOVINE LEUKEMIA VIRUS
}

\author{
L.M. Ishchenko ${ }^{1}$, V.V. Nedosekov ${ }^{1}$, V.D. Ishchenko', O.Yu. Kepple , \\ V.V.Tkachenko ${ }^{1}$, T.A. Tkachenko ${ }^{1}$, S.V. Midyk ${ }^{1}$, T.V. Nemova ${ }^{1}$, \\ S.D. Melnychuk', V.G Spyrydonov ${ }^{3}$,V.O. Ushkalov ${ }^{I}$ \\ ${ }^{I}$ National University of Life and Environmental Sciences of Ukraine, \\ 15 Heroiv Oborony Str., Kyiv, 03041, Ukraine \\ ${ }^{2}$ Institute of Veterinary Medicine, NAAS of Ukraine, \\ 30 Donetska Str., Kyiv, 03151, Ukraine \\ ${ }^{3}$ China-Ukraine Life Science Research Institute, \\ Zhuji,311800, China \\ e-mail: ischenko_lm@ukr.net
}

\begin{abstract}
Enzootic bovine leukosis caused by a bovine leukemia virus has a significant economic impact and is reported in World Organization for Animal Health(OIE). Aim. The purpose of our work was to improve the nested polymerase chain reaction (PCR) recommended by the OIE conducting it second-stage in real-time (RT) PCR. Such modification does not require the stage of gel electrophoresis and consequently reduces contamination risks and prevents false positive results. Methods. Primers that are recommended by the Manual of Diagnostic Tests and Vaccines for Terrestrial Animals (OIE) were used for the first amplification stage. For the second stage of the proposed modification of nested PCR, the primers and probe were designed based on the alignment of the sequences envelope gene of different isolates of bovine leukemia virus including Ukrainian isolates. Amplification of the internal control was carried out for the second stage to prevent false negative results. Results. Comparative studies of 48 blood samples for bovine leukemia virus identification by a proposed nested RT-PCR, nested PCR recommended by the protocol of the OIE, and RT-PCR were conducted. The sample panel included both positive and negative samples. A $100 \%$ match of the results of the bovine leukemia virus presence in nested PCR proposed by the OIE and in our proposed nested RT-PCR was obtained. Comparative analysis of results that were obtained using the RT-PCR and the proposed nested RT-PCR showed that false-negative results in 5 samples and 3 doubtful results that require retesting were obtained by use of $R T-P C R$. The interpretation of the results using nested RT-PCR is more efficient than RT-PCR since the cycle threshold value of positive samples obtained using RT-PCR was in the range of 24-40 cycles, whereas in the case of nested RT-PCR using, the value of Ct was in the range of 4-20 cycles. Conclusions. Proposed nested PCR modification includes the combination of the OIE recommendation about nested PCR and the reduction of the risk of contamination by conducting the second stage in RT-PCR. Results of approbation of proposed nested RT-PCR give a reason to recommend it for the identification of bovine leukemia virus.
\end{abstract}

Keywords: Bovine leukemia virus, nested PCR, Real-time PCR.

Enzootic bovine leucosis (EBL) is a spread around the world disease of cattle caused by the bovine leukemia virus (BLV). Cattle may be infected at any age, including the embryonic stage. The virus causes a persistent, life-long infection in a subset of B-cells. Malignant tumors (lymphomas) ultimately develop in $2-5 \%$ of infected animals predominantly in adult cattle older than 3-5 years [1-4]. Nowadays EBL is seen general biological importance because BLV is structurally and functionally related to other primate and human retroviruses (primate T-lymphotropic virus 1, 2 and
3 (PTLV-1, -2, -3). Therefore BLV often is used as a model object for the study of molecular mechanisms of neoplasia induced by retroviruses [5-7].

EBL is notified by the World Organization for Animal Health (OIE) due to significant economic losses (the importation restrictions, forced slaughter of seropositive animals) [8]. EBL has been stably registered in Ukraine for many years but the data of infected animals' amount are often controversial [9].

Considering EBL is an incurable disease, timely diagnosis and eradication of infected animals is 
a key to disease control. Serological methods like agar gel immunodiffusion (AGID), enzymelinked immunosorbent assay (ELISA) and DNAbased tests polymerase chain reaction (PCR), quantitative polymerase chain reaction (qPCR) should be used for EBL diagnosis according to OIE recommendation $[10,11]$. There are also data on the effectiveness of biosensor-based method using [12].

Techniques based on DNA amplification methods allow direct detection of proviral DNA or viral RNA and they are "gold standard". PCR is the primary method to detect the latent stage of EBL, to verify the doubtful results of serological tests, to identify infected calves up to 6 months and also to distinguish lymphoma viral etiology and neoplasms [13-18]. Nested PCR is recommended to use as more sensitive among other variants of PCR according to the OIE protocol for EBL diagnostic. However, the use of nested PCR requires maximal contamination prevention activities that are sometimes difficult to achieve in routine diagnostic laboratories with a large flow of samples. The most contamination endangered phase is the stage of gel electrophoresis of amplification products.

The aim of our work was to improve the nested PCR method recommended by the OIE by conducting it second-stage in real-time (RT) PCR. Such a modification does not require the stage of gel electrophoresis and consequently reduces contamination risks and prevents false positive results.

Materials and methods. Primers and Probes

For the first stage our modified nested PCR we used primers recommended by the OIE protocol [10]. For the second stage primers and probe were designed using the Primer Express (Applied Biosystems). To design primers we provided the alignment of sequences gene env of different BLV isolates which are presented in Gen-Bank including the sequences of BLV isolates from Ukraine (GenBank IDs: K02120, JF720357.2, AF399703.3, HE967301.1, D00647.1, EF065647.1 AF257515.1, EU266061.1，KR063246.1， KR063245.1, KX470607.1, KX470606.1, KX470605.1, KX470604.1, KX470603). PCR amplification of the gene prion protein (PRP) that is specific for cattle (internal control) was carried out for the second stage to prevent false negative results. The sequences and information of the primers are shown in the Table 1.

\section{Sample}

48 blood samples from BLV of infected cattle from two farms of Ukraine (Rivne and Kyiv regions) were used for approbation of proposed nested RT-PCR. Blood samples were collected from the jugular vein in vacutainer plastic tubes with ethylenediaminetetraacetic acid (EDTA).

\section{DNA extraction}

Total genomic DNA from blood samples was isolated using method described by R. Boom et al. [19].

\section{Nested PCR}

Nested PCR was conducting with primers 1 and 2 (see Table 1) according to OIE manual [10].

Nested RT-PCR

The reaction mixture for the first stage of amplification contained $10 \times$ PCR buffer containing $25 \mathrm{mM} \mathrm{MgCl}_{2}$ (Thermo Fisher Scientific), $0.2 \mathrm{mM}$ each of the dNTPs (Thermo Fisher Scientific), $0.5 \mu \mathrm{M}$ each of the primers (primer 1, Table 1), $0.2 \mathrm{U} / \mu \mathrm{l}$ of uracil-DNA glycosylase (Thermo Fisher Scientific) and $U / \mu l$ Taq polymerase (Thermo

\section{Table 1}

Sequence of primers and probes

\begin{tabular}{|c|c|c|c|}
\hline No. & Name of primers & Sequence primers & Reference \\
\hline \multirow{2}{*}{1} & OBLV1A & ctt tgt gtg cca agt ctc cca gat aca & \multirow{2}{*}[10]{} \\
\hline & OBLV6A & cca-aca-tat-agc-aca-gtc-tgg-gaa-ggc & \\
\hline \multirow{2}{*}{2} & OBLV3A & ctg-taa-atg-gct-atc-cta-aga-tct-act-ggc & \multirow{2}{*}[10]{} \\
\hline & OBLV5A & gac-aga-ggg-aac-cca-gtc-act-gtt-caa-ctg & \\
\hline \multirow{3}{*}{3} & BLV For & ccc ctg atc acc ttt tet tta ca & \multirow{3}{*}{ Current study } \\
\hline & BLV Rev & agg gaa ccc agt cac tgt tca & \\
\hline & BLV Probe & $\mathrm{FAM}^{*}$-atc cet gat ccc cet caa ccc ga-BHQ1** & \\
\hline \multirow{3}{*}{4} & PRP For & acg-tgg-gcc-tct-gca-aga & \multirow{3}{*}{ Current study } \\
\hline & PRP Rev & gac-tgc-cct-gct-ctg-ggt-atc & \\
\hline & PRP Probe & VIC***-cga cca aaa cct gga gga gga tgg a-BHQ1 & \\
\hline
\end{tabular}

Legend: *6-Carboxyfluorescein, **Black Hole Quencher ${ }^{\mathrm{TM}}$ dyes ***2'-chloro-7'-phenyl-1,4-dichloro-6carboxyfluorescein. 
Fisher Scientific). The amount of DNA was 100 150 ng. Final reaction volume was $25 \mu 1$. Thermal cycling conditions were $10 \mathrm{~min}$ at $50^{\circ} \mathrm{C}, 5 \mathrm{~min}$ at $94{ }^{\circ} \mathrm{C}$, followed by 5 cycles of $30 \mathrm{~s}$ at $95^{\circ} \mathrm{C}, 30 \mathrm{~s}$ at $53^{\circ} \mathrm{C}, 60 \mathrm{~s}$ at $72{ }^{\circ} \mathrm{C}$, followed by 25 cycles of $30 \mathrm{~s}$ at $95^{\circ} \mathrm{C}, 30 \mathrm{~s}$ at $58{ }^{\circ} \mathrm{C}, 60 \mathrm{~s}$ at $72^{\circ} \mathrm{C}$.

Second stage of amplification was performed by RT-PCR (CFX 96 BioRad, Germany). The reaction mixture for the second stage of amplification contained $10 \mathrm{x}$ PCR buffer containing $25 \mathrm{mM} \mathrm{MgCl}_{2}$ (Thermo Fisher Scientific, USA), $0.2 \mathrm{mM}$ each of the dNTPs (Thermo Fisher Scientific, USA), $0.5 \mu \mathrm{M}$ each of the primers and $0.25 \mu \mathrm{M}$ of probe (Metabion, Germany) for detecting proviral DNA of BLV (primer 3, Table 1), $0.5 \mu \mathrm{M}$ each of the primers and $0.25 \mu \mathrm{M}$ of probe (Metabion, Germany) for detecting the fragment of the PRP gene (primer 4, Table 1) and $U / \mu$ l of Taq polymerase (Thermo Fisher Scientific, USA). The PCR product of the first amplification step was added in an amount of $5.0 \mu \mathrm{l}$. Final reaction volume was $25 \mu 1$. Thermal cycling conditions were $5 \mathrm{~min}$ at $94{ }^{\circ} \mathrm{C}$, followed by 40 cycles of $30 \mathrm{~s}$ at $95{ }^{\circ} \mathrm{C}$, $30 \mathrm{~s}$ at $60^{\circ} \mathrm{C}, 30 \mathrm{~s}$ at $72{ }^{\circ} \mathrm{C}$.

$R T-P C R$

Amplification was performed by RT-PCR (CFX 96 BioRad, Germany). The reaction mixture for amplification contained $10 \times$ PCR buffer containing $25 \mathrm{mM} \mathrm{MgCl}$ (Thermo Fisher Scientific, USA), $0.2 \mathrm{mM}$ each of the dNTPs (Thermo Fisher Scientific, USA), $0.1 \mu \mathrm{M}$ each of the primers and $0.5 \mu \mathrm{M}$ of probe (Metabion, Germany) for detecting proviral DNA of BLV (primer 3, Table 1), $0.25 \mu \mathrm{M}$ of each of the primers and $0.25 \mu \mathrm{M}$ of probe (Metabion, Germany) for detecting the fragment of the PRP gene (primer 4, Table 1) and
$\mathrm{U} / \mu \mathrm{l}$ of Taq polymerase (Thermo Fisher Scientific, USA). The PCR product of the first amplification step was introduced in an amount of $5.0 \mu$ l. Final reaction volume was $25 \mu \mathrm{l}$. Thermal cycling conditions were $5 \mathrm{~min}$ at $94{ }^{\circ} \mathrm{C}$, followed by 45 cycles of $30 \mathrm{~s}$ at $95{ }^{\circ} \mathrm{C}, 30 \mathrm{~s}$ at $60^{\circ} \mathrm{C}, 30 \mathrm{~s}$ at $72{ }^{\circ} \mathrm{C}$.

\section{ELISA}

Antibody detection by ELISA using the «Bovine Leukemia Virus Antibody Test Kit» (VMRD Inc., USA) was performed.

Statistical methods in the study were not used.

Results. Selecting the optimal primers concentration for the second stage of the nested RT$P C R$. Considering that for the second stage of the proposed nested RT-PCR the detection for internal control was used, we determine the optimal proportion of primers concentration for target and internal control. This study is important because the target amplification will be higher than the internal control because it's been accumulated during the first stage of amplification [20]. The results were estimated by the value of the cycle threshold and the level of fluorescence (Table 2).

As can be seen in Table 2, at a primer's concentration of $10 \mathrm{pM}$ for the detection of target and $2.5 \mathrm{pM}$ for the detection of internal control, no amplification of the internal control was observed. With the concentration primers of $10 \mathrm{pM}$ for the target and $10 \mathrm{pM}$ for the internal control, there was a low level of reference fluorescence of the latter (200 vs. 1200 in the target). At concentration primers of $2.5 \mathrm{pM}$ for target and for internal control, a low level of relative fluorescence for both targets was observed. Therefore, as a result of the study,

\section{Table 2}

\section{Value of the cycle threshold and the level of fluorescence}

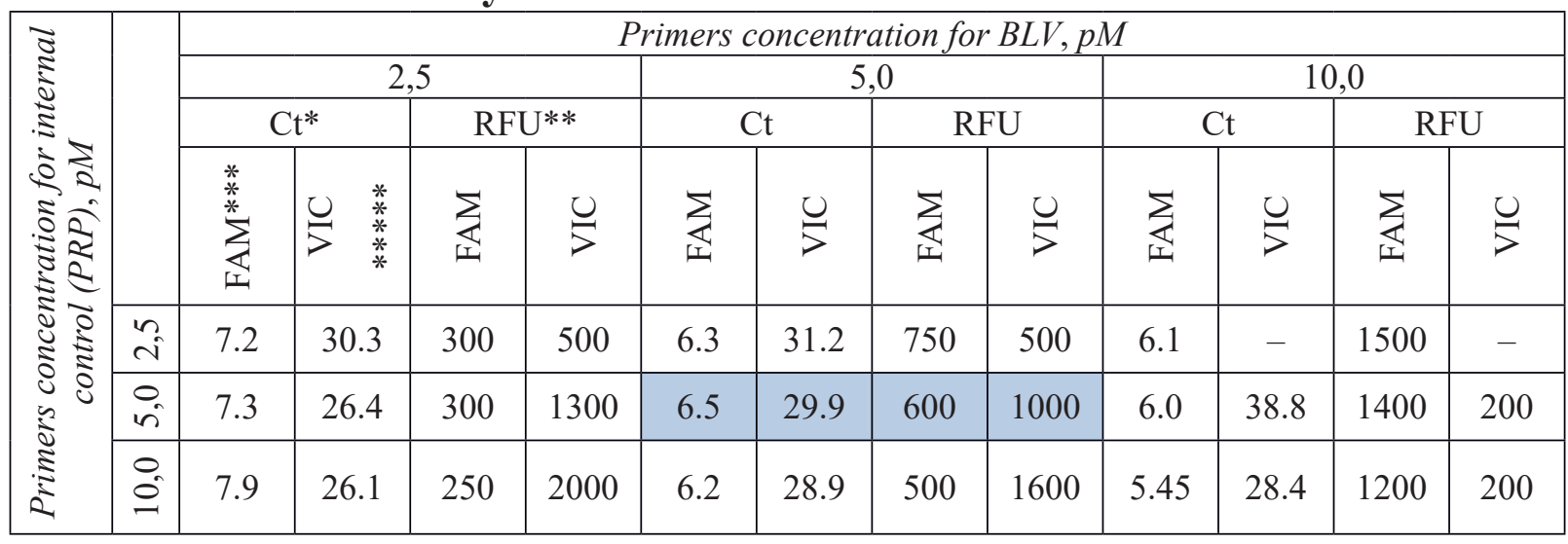

Legend: $* \mathrm{Ct}$ - cycle threshold, $* * \mathrm{RFU}$ - reference fluorescence unit, ${ }^{*} * \mathrm{FAM}$ - detection channel bovine leukemia virus, **** VIC - detection channel internal control. 
we recommend a concentration of $5 \mathrm{pM}$ for both targets, which gives a satisfying value to both the threshold cycle $\mathrm{Ct}$ and the level of reference fluorescence.

Investigation of the proposed nested RT-PCR compared with nested PCR and RT-PCR

For better understanding the appropriateness and effectiveness of the proposed nested RT-PCR we conducted comparative studies of 48 blood samples by different variants of PCR. Samples were collected in different farms and tested by ELISA. The sample panel included both positive and negative samples. 20 (41.7\%) samples were negative in all variants of PCR. 28 samples were diverging, the results of them are shown in Table 3.
As we can see from Table 3, we obtained a $100 \%$ match of the BLV presence by nested PCR proposed by OIE and by our proposed nested PCR with conducting the second stage in RT-PCR. Nevertheless, our nested PCR modification method is more convenient in routine diagnostics because it does not require the gel electrophoresis stage. Besides that, the detection of an internal control gene allows to control the quality and quantity of DNA extraction.

Comparing the results of the RT-PCR and the proposed nested RT-PCR showed us that the use of RT-PCR resulted in 5 false negative samples and 3 doubtful samples that required retesting. In addition, attention should be paid to the difference

\section{Table 3}

\section{The results of BLV identification in blood samples of cattle by using different PCR technologies}

\begin{tabular}{|c|c|c|c|c|c|c|}
\hline \multirow{2}{*}{$\begin{array}{l}\text { Number of } \\
\text { samples }\end{array}$} & \multirow{2}{*}{$\begin{array}{l}\text { ELISA } \\
\text { results }\end{array}$} & \multirow{2}{*}{$\begin{array}{c}\text { Nested PCR } \\
\text { proposed OIE* }\end{array}$} & \multicolumn{2}{|c|}{$\begin{array}{c}\text { Proposed Nested } \\
\text { RT-PCR } \\
\end{array}$} & \multicolumn{2}{|c|}{$\begin{array}{c}\text { Real-time } \\
\text { PCR*** }\end{array}$} \\
\hline & & & Results & $\mathrm{Ct}_{\mathrm{FAM}} * * * *$ & Results & $\mathrm{Ct}_{\text {FAM }}$ \\
\hline 1 & - & - & - & - & + & 39,1 \\
\hline 2 & + & + & + & 6,2 & + & 29 \\
\hline 3 & + & + & + & 9.6 & + & 31.8 \\
\hline 4 & + & + & + & 19.2 & - & - \\
\hline 5 & + & + & + & 7.0 & + & 28.2 \\
\hline 6 & + & + & + & 8.6 & + & 30.7 \\
\hline 7 & + & + & + & 10.7 & + & 32.0 \\
\hline 8 & + & + & + & 13.3 & + & 37.7 \\
\hline 9 & + & + & + & 16.0 & - & - \\
\hline 10 & + & - & - & - & - & - \\
\hline 11 & + & + & + & 8.9 & - & - \\
\hline 12 & - & - & - & - & + & 37.9 \\
\hline 13 & + & + & + & 10.4 & - & 36.7 \\
\hline 14 & + & + & + & 9.8 & - & 36.9 \\
\hline 15 & + & + & + & 5.8 & - & 35.9 \\
\hline 16 & + & + & + & 6.3 & - & 29 \\
\hline 17 & + & + & + & 4.9 & + & 25 \\
\hline 18 & + & + & + & 16.67 & - & - \\
\hline 19 & + & + & + & 4.77 & + & 26.1 \\
\hline 20 & + & + & + & - & & - \\
\hline 21 & - & - & - & - & + & 39.7 \\
\hline 22 & + & + & + & 19.7 & - & - \\
\hline 23 & + & + & + & 5.3 & + & 25.1 \\
\hline 24 & + & + & + & 20.1 & - & - \\
\hline 25 & + & + & + & 14.8 & - & 35.3 \\
\hline 26 & + & + & + & 10.1 & - & 32.7 \\
\hline 27 & + & - & - & - & - & - \\
\hline 28 & + & + & + & 8.7 & 39 & 39.25 \\
\hline
\end{tabular}

Legend: * primers 1, 2 were used; ** primers 1, 3, 4 were used; *** primers 3 were used (see Table 1); ****Cycle threshold. 
in the values of the Ct cycle of positive samples obtained using the above methods. The $\mathrm{Ct}$ value of positive samples obtained using RT-PCR was in the range of 24-40 cycles, whereas in the case of nested RT-PCR, the value of Ct was in the range of 4-20 cycles. Therefore, the interpretation of the study results using nested RT-PCR is more efficient than RT-PCR (Fig.1).

$\mathbf{A}$

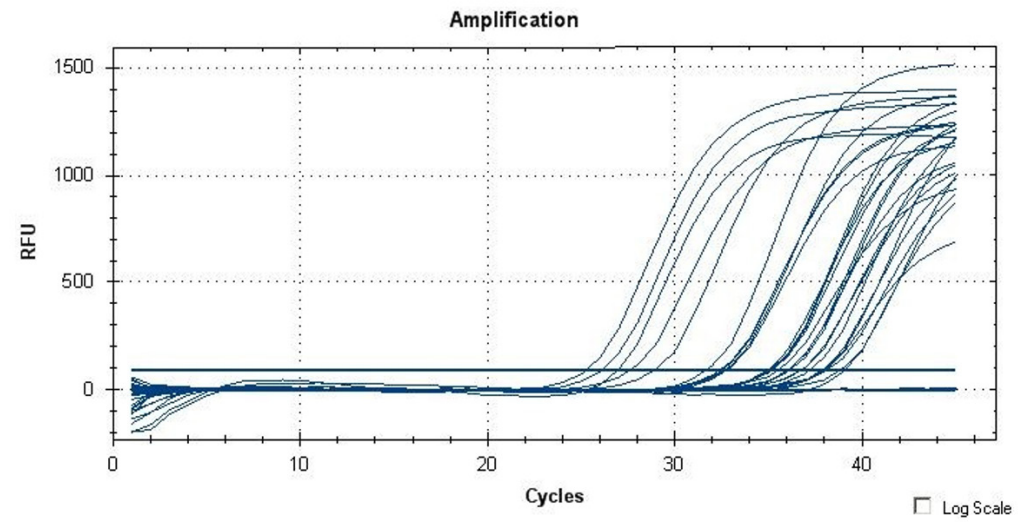

B

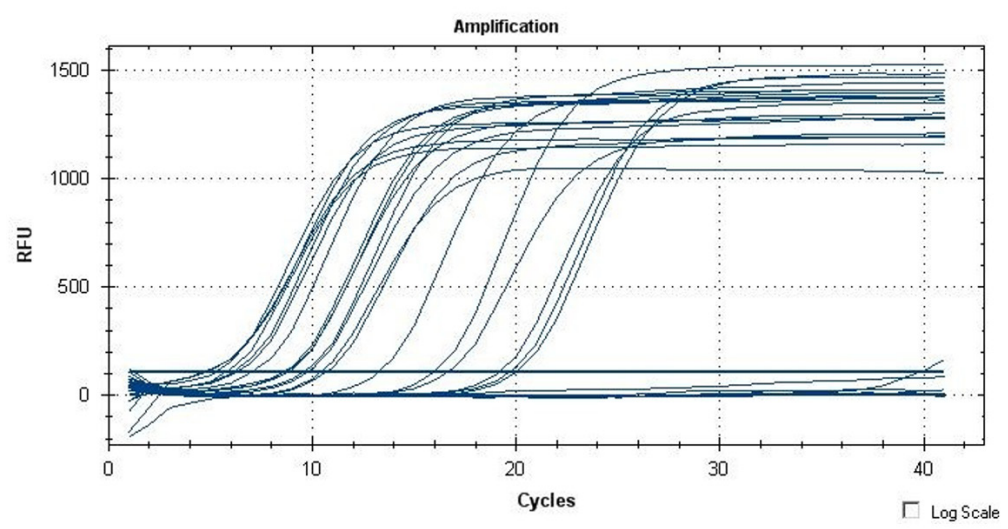

F i g 1. Amplification curves of bovine leukemia virus identification: A) Real-time PCR; B) Nested RT-PCR

The interpretation of the results with high values of the $C t$ often gives some trouble since after 35 cycles the risk of a non-specific amplification product that can cause the false positive results increases. On the other hand, 35 cycles of amplification may give not sufficient sensitivity of PCR for BLV identification, because the disease is often characterized by an aleukemic form, when persistent lymphocytosis is not typical, and there are not many infected blood cells in such animals. For this reason, the use of nested PCR as more sensitive is recommended.

Discussion. In the last years topicality of the BLV is increasing in view of new information related to human breast cancer [21]. It leads to new research in this area and the development of new methods of BLV identification in cattle to eradicate infected animals [17, 18, 22-26].
PCR using for the diagnostic of bovine leukemia in Ukraine is debatable. To some extent, an explanation for this may be a conservative persuasion about the superiority of serological methods. However, in our opinion, the lack of experience of PCR using in the diagnostic system of veterinary medicine laboratories it also plays a great role. There are economic and methodological reasons for this. The equipment and consumables for PCR laboratories are expensive, also in Ukraine sometimes there is an incomplete understanding of the role of PCR in the diagnostic and eradication of enzootic bovine leukemia.

According to the OIE guidelines, PCR is an arbitration method in doubtful cases. It is also the main method of detecting infected animals before moving because it detects infected animals at a latent stage when serological methods are uninformative $[10,11]$. Therefore, according to the OIE's 
recommendations, the latest edition of "Instructions for the prevention and eradication of cattle from bovine leukemia" in Ukraine include PCR as one of method that can be used for the EBL diagnostic [27].

In our study we improve the nested PCR for BLV identification in cattle that is recommended by OIE by conducting a second stage in RT-PCR. We used primers recommended by OIE as external primers set [10], we designed internal primers by using the Primer Express. In addition, for the second stage of the proposed nested RT-PCR we designed primers for the identification of a specific prion gene for cattle (internal control) that allows controlling the process of DNA extraction in each sample. Given that we used multiplex format PCR for the second stage of nested RT-PCR, it was determined the optimal proportion of primers concentration for target and internal control. It was important because in the multiplex analysis in one tube takes place an amplification of two or more independent systems that compete for the components of the reaction, and the inhibition of one of them can occur at different efficiency of their amplification [20].

The main purpose of our study was to compare the sensitivity of the proposed modification of nested PCR with the nested PCR recommended by the OIE. It was important because the primers and probes for the second stage of proposed PCR were developed by us. The other validation parameters of these primers were reported in our previous work [28].

Negative control was used in all variants of PCR to prevent false positive results. In addition, we recommend to use uracil-DNA glycosylase for the first stage of nested RT-PCR as one more way to prevent contamination.

As we can see from the study, all the results obtained with the proposed modification of PCR coincided with the PCR recommended by the OIE. Further, we compared both nested PCR with RTPCR using primers that we designed for the second stage of proposed nested RT-PCR. Using RT-PCR for identification of BLV in blood samples we got both false positive and false negative results. In addition, the interpretation of the results of the nested RT-PCR is more convenient because positive samples have significantly smaller values of cycle threshold. The difference between the $\mathrm{Ct}$ values is related to the number of PCR cycles. In RT-PCR 45 cycles are used while in the nested RT-PCR products of amplification accumulate for 30 cycles in the first stage and 40 cycles in the second stage. Since the value of the $\mathrm{Ct}$ is inversely proportional to the amount of target nucleic acid in the sample, using nested RT-PCR gives an accumulation of amplicons faster than in RT-PCR that impact on lower $\mathrm{Ct}$ values. We suppose that it is important for the identification of BLV in animals with a small number of infected lymphocytes. There is possibly that conducting of 45 cycles of RT-PCR amplification in such animals can lead to false negative study results. The use of more than 45 cycles of amplification in PCR generally is not recommended because it is a risk of non-specific amplification products, which can be considered as false positive results and that had shown in our research. However, it should be noted that in the work of Rola-Luszczak et al. developed RT-PCR with 50 cycles had high sensitivity [29].

It is interesting that two positive samples in ELISA were not confirmed by any of the PCR variants. The discrepancy between the results of serological and molecular genetic studies for the diagnosis of bovine leukemia is a very common and debatable issue and in some studies may reach $30 \%$ [29, 30]. Moreover, the discrepancy is determined often even using different ELISA kits and different sets primers for PCR [31-34].

Therefore, the results of our proposed nested RT-PCR approbation give a reason to recommend it for the identification of BLV. The advantages of this PCR modification include the combination of the OIE's recommendation about nested PCR and the reduction of the risk of contamination by conducting the second stage in RT-PCR.

Conclusions. Proposed nested PCR modification includes the combination of the World Organization for Animal Health recommendation about nested PCR and the reduction of the risk of contamination by conducting the second stage in RT-PCR. Results of approbation of proposed nested RT-PCR give a reason to recommend it for the identification of bovine leukemia virus. 


\section{УДОСКОНАЛЕННЯ ГНІЗДОВОЇ ПЛР ДЛЯ ДЕТЕКЦЇ̈ ВІРУСУ ЛЕЙКОЗУ ВЕЛИКОЇ РОГАТОЇ ХУДОБИ}

\author{
Л.М. Іщенко ${ }^{\prime}$ В.В. Недоссков ${ }^{\prime}$ В.Д. Іщенко ${ }^{1}$, \\ О.Ю. Кеппл ${ }^{1}$ В.В. Ткаченко ${ }^{1}$, Т.А. Ткаченко ${ }^{\prime}$, \\ С.В. Мідик ${ }^{1}$, Т.В. Немова ${ }^{1}$, С.Д. Мельничук ${ }^{2}$, \\ B.Г. Спиридонов ${ }^{3}$, В.О. Ушкалов ${ }^{I}$ \\ ${ }^{1}$ Наиіональний університет біоресурсів \\ і природокористування України, \\ вул. Героїв Оборони, 15, Київ, 03041, Україна \\ ${ }^{2}$ Інститут ветеринарної медицини НААН \\ Украйни,в ул. Донечька, 30, Київ, 03151, Україна \\ ${ }^{3}$ Китайсько-Украйнський науково-дослідний \\ інститут, Чжуизі, 311800, Китай

\section{Резюме}

Згідно з протоколом Всесвітньої організації охорони здоров'я тварин для діагностики лейкозу великої рогатої худоби методом полімеразної ланцюгової реакції необхідно застосовувати іiї гніздовий формат як найбільш чутливий. Однак висока чутливість одночасно $є$ і її недоліком через високий ризик контамінації продуктами ампліфікації та, як наслідок - отримання псевдопозитивних результатів. Найбільш небезпечним етапом 3 огляду на контамінацію $є$ електрофорез продуктів ампліфікації в агарозному гелі. Мета. Метою роботи було удосконалити гніздовий формат полімеразної ланцюгової реакції, який рекомендується протоколом Всесвітньої організації охорони здоров'я, шляхом проведення другої стадії методом полімеразної ланцюгової реакції в реальному часі, що дозволить зменшити ризик контамінації, оскільки не буде потреби у проведенні електрофорезу в агарозному гелі для інтерпретації результатів. Методи. Для першої стадії запропонованої модифікації полімеразної ланцюгової реакції було використано нуклеотидну послідовність праймерів, рекомендованих протоколом Всесвітньої організації охорони здоров'я тварин. Для другої стадії полімеразної ланцюгової реакції проведено дизайн праймерів та флуоресцентного зонду на основі аналізу нуклеотидних послідовностей ділянки оболонкового гену відомих ізолятів вірусу лейкозу, включаючи українські ізоляти. Крім того, для другої стадії було проведено дизайн праймерів для ідентифікації гену, специфічного для великої рогатої худоби, що дозволяє контролювати процес екстракції нуклеїнової кислоти у кожному зразку. Результати. Досліджено різне співвідношення концентрації праймерів для цільової мішені та внутрішнього контролю та встановлено, що мак- симальна ефективність обох мішеней досягається за концентрації 5 рМ для вірусу лейкозу та 5 рM для внутрішнього контролю. Проведено порівняльні дослідження 48 зразків крові щодо наявності вірусу лейкозу за допомогою запропонованої модифікації гніздової полімеразної ланцюгової реакції, гніздової полімеразної ланцюгової реакції, рекомендованої протоколом Всесвітньої організації охорони здоров'я тварин та полімеразної ланцюгової реакції в реальному часі з використанням праймерів, які використані для другої стадії запропонованої модифікації двостадійної полімеразної ланцюгової реакції. Панель зразків включала як позитивні, так і негативні зразки. Отримано 100 \% співпадіння результатів щодо наявності вірусу лейкозу з використанням запропонованої модифікації гніздової полімеразної ланцюгової реакції та гніздової полімеразної ланцюгової реакції, рекомендованої протоколом Всесвітньої організації охорони здоров'я тварин. Порівнюючи результати, отримані за допомогою полімеразної ланцюгової реакції в реальному часі та запропонованої модифікації гніздової полімеразної ланцюгової реакції, встановлено, що при використанні полімеразної ланцюгової реакції в реальному часі було отримано 5 хибнонегативних результатів дослідження і 3 сумнівних результати, які потребують повторного дослідження. Характерною є різниця у значеннях граничного циклу $\mathrm{Ct}$ позитивних зразків. Так, при використанні полімеразної ланцюгової реакції в реальному часі значення Ct було у межах 2440 циклів, а за використання запропонованої гніздової полімеразної ланцюгової реакції - у межах 4-20 циклів, що значно полегшує інтерпретацію результатів дослідження. Висновки. Запропонована нами модифікація гніздової полімеразної ланцюгової реакції поєднує в собі рекомендації Всесвітньої організації охорони здоров'я тварин щодо ідентифікації вірусу лейкозу за допомогою гніздової полімеразної ланцюгової реакції та зменшення ризику контамінації за рахунок проведення другої стадії в режимі реального часу, що $є$ зручнішим у рутинній діагностиці. Крім того, ампліфікація гену, специфічного для великої рогатої худоби у запропонованій модифікації, дозволяє контролювати якість та кількість екстракції нуклеїнової кислоти та попереджати хибнонегативні результати дослідження.

Ключові слова: вірус лейкозу великої рогатої худоби, гніздова ПЛР, ПЛР в реальному часі. 
1. Gillet N, Florins A, Boxus M, Burteau C, Nigro A, Vandermeers F, et al. Mechanisms of leukemogenesis induced by bovine leukemia virus: prospects for novel anti-retroviral therapies in human. Retrovirology. 2007; 18(4):1-32. https:// doi.org/10.1186/1742-4690-4-18

2. Bartlett PC, Ruggiero VJ, Hutchinson HC, Droscha CJ, Norby Bo, et al. Current Developments in the Epidemiology and Control of Enzootic Bovine Leukosis as Caused by Bovine Leukemia Virus. Pathogens. 2020; 9(12):1058. https://doi. org/10.3390/pathogens9121058

3. Juliarena MA, Barrios CN, Lützelschwab CM, Esteban EN, Gutiérrez SE. Bovine leukemia virus: current perspectives. Virus Adaptation and Treatment. 2017; 9:13-26. https://doi.org/ 10.2147/VAAT.S113947

4. Polat M, Takeshima SN, Aida Y. Epidemiology and genetic diversity of bovine leukemia virus. Virol J. 2017; 14:209. https://doi.org/10.1186/ s12985-017-0876-4

5. Jaworski JP, Petersen MI, Carignano HA, Trono KG. Spontaneous virus reactivation in cattle chronically infected with bovine leukemia virus. BMC Vet Res. 2019; 15:150. https://doi. org/10.1186/s12917-019-1908-7

6. Rodriguez SM, Florins A, Gillet N, de Brogniez A, Sanchez-Alcaraz MT, Boxus M, et al. Preventive and Therapeutic Strategies for Bovine Leukemia Virus: Lessons for HTLV. Viruses-Basel. 2011; 3:1210-48. https://doi.org/10.3390/ v3071210

7. Rosewick N, Durkin K, Artesi M, Marçais A, Hahaut V, Griebel P, et al. Cis-perturbation of cancer drivers by the HTLV-1/BLV proviruses is an early determinant of leukemogenesis. Nat Commun. 2017; 8:15264 https://doi.org/10.1038/ ncomms 15264

8. Ott SL, Johnson R, Wells SJ. Association between bovine-leukosis virus seroprevalence and herd-level productivity on US dairy farms. Preventive Veterinary Medicine. 2003; 61(4):249-262. https://doi.org/10.1016/j.prevetmed.2003.08.003

9. Pyskun A, Kornienko L, Tsarenko T, Aliekseieva GB. Retrospective analysis of the epi- zootic situation of enzootic bovine leukosis in Ukraine in 1994-2019. Regulatory Mechanisms in Biosystems. 2020; 11(3):372-377. https://doi. org/10.15421/022057

10. World Organization for Animal Health [OIE]. Manual of diagnostic tests and vaccines. Chapter 2.4.11. Enzootic bovine leukosis (NB: Version adopted in May 2012). Paris: OIE; 2012. https:// www.oie.int/doc/ged/D7709.PDF

11. World Organization for Animal Health [OIE]. Terrestrial Animal Health Code - 28/06/2019. Section 11. Chapter 11.6. Enzootic bovine leucosis (Access online). https://www.oie.int/index. php?id $=169 \& \mathrm{~L}=0 \&$ htmfile $=$ chapitre_ebl.htm

12. Ruban Y, Shpyrka N, Pareniuk O, Galat M, Savchuk M, Ishchenko L, et al. BLV Leucosis Biosensor Based on $\mathrm{ZnO}$ Nanorods Photo Luminescence. In: IEEE 37th International Conference on Electronics and Nanotechnology (ELNANO); 2017; 333-338.

13. Jacobs RM1, Song Z, Poon H, Heeney JL, Taylor JA, Jefferson B, Vernau W, Valli VE. Proviral detection and serology in bovine leukemia virus-exposed normal cattle and cattle with lymphoma. Can J Vet Res. 1992; 56(4):339-48.

14. Eaves FW, Molloy JB, Dimmock CK, Eaves LE. A field evaluation of the polymerase chain reaction procedure for the detection of bovine leukaemia virus proviral DNA in cattle. Vet Microbiol. 1994; 39(3-4):313-321. https://doi. org/10.1016/0378-1135(94)90167-8

15. Alvarez I, Porta NG, Trono K. Detection of Bovine Leukemia Virus RNA in Blood Samples of Naturally Infected Dairy Cattle. Vet Sci. 2019; 6(3):66. https://doi.org/10.3390/vetsci6030066

16. Blankenstein P, Fechner H, Looman A, Beier D, Marquardt O, Ebner D. Polymerase chain reaction (PCR) for detection of BLV proviruses a practical complement BLV diagnostics? Berl Munch Tierarztl Wochenschr. 1998; 111(5):180186.

17. Jimba M, Takeshima SN, Matoba K, Endoh D, Aida Y. BLV-CoCoMo-qPCR: Quantitation of bovine leukemia virus proviral load using the CoCoMo algorithm. Retrovirology. 2010; 7:91. https://doi.org/10.1186/1742-4690-7-91 
18. Petersen MI, Alvarez I, Trono KG, Jaworski JP. Quantification of bovine leukemia virus proviral DNA using a low-cost real-time polymerase chain reaction. 2018; J Dairy Sci. 101(7):63666374. https://doi.org/10.3168/jds.2017-14253

19. Boom R, Sol C, Salimans M, Jansen CL, Wertheim-van Dillen PM, van der Noordaa J. Rapid and Simple Method for Purification of Nucleic Acids. J Clin Microbiol. 1990; 28(3):495-503. https://dx.doi.org/10.1128/JCM.28.3.495503.1990

20. Sint D, Raso L, Traugott M. Advances in multiplex PCR: balancing primer efficiencies and improving detection success. Methods in Ecology and Evolution. 2012; 3(5):898-905. doi: 10.1111/j.2041-210X.2012.00215.x

21. Gao A, Kouznetsova VL, Tsigelnyc IF. Bovine leukemia virus relation to human breast cancer: Meta-analysis. Microb Pathog. 2020; 149:104417. https://doi.org/10.1016/j.micpath.2020.104417

22. Buehring GC, DeLaney A, Shen H, Chu DL, Razavian N, Schwartz DA, et al. Bovine leukemia virus discovered in human blood. BMC Infect Dis. 2019; 19:297. https://doi.org/10.1186/ s12879-019-3891-9

23. Uchiyama H, Suzukia C, Nikaidoa S, Shibuyaa K, Satoc R, Maedad Y, et al. Variations in the viral genome and biological properties of bovine leukemia virus wild-type strains. Virus Research. 2018; 253:103-111. https://doi.org/10.1016/j.virusres.2018.06.005

24. Mitoma S, Elhanafy E, Nguyen HT, Mai NT, Hara A, Duangtathip K, et al. Establishment of a novel diagnostic test for Bovine leukemia virus infection using direct filter PCR. Transboundary and Emerging Disease. 2020 Feb 08; 67(4):16711676. https://doi.org/10.1111/tbed.13506

25. Ruggiero VJ, Norby B, Benitez OJ, Hutchinson H, Sporer KRB, Droscha C, et al. Controlling bovine leukemia virus in dairy herds by identifying and removing cows with the highest proviral load and lymphocyte counts. J Dairy Sci. 2019 Oct;
102(10):9165-9175. https://doi.org/10.3168/ jds.2018-16186

26. Bartlett PC, Ruggiero VJ, Hutchinson HC, Droscha CJ, Norby Bo, et al. Current Developments in the Epidemiology and Control of Enzootic Bovine Leukosis as Caused by Bovine Leukemia Virus. Pathogens. 2020; 9(12):1058. https://doi. org/10.3390/pathogens 9121058

27. [Instrukciya $\mathrm{z}$ profilaktiki ta ozdorovlennya velikoyi rogatoyi hudobi vid lejkozu / zatv. nakazom Derzhavnogo komitetu veterinarnoyi medicini Ukrayini 21.11.07., №28 ; zareyestr. v Ministerstvi yusticiyi 11.01.08 № 12/14703]. URL: http://zakon3.rada.gov.ua/laws/show/ z0012-08. Ukrainian.

28. Ishchenko LM, Spyrydonov VG, Ishchenko VD, Melnychuk SD. [Validation of PCR methods for bovine leukemia diagnosis]. Scientific Messenger of Lviv National University of Veterinary Medicine and Biotechnologies named after S.Z. Gzhytskyj. 2014; 2 (1):95-102. Ukrainian.

29. Rola-Luszczak M, Finnegan C, Olech M, Choudhury B, Kuzmak J. Development of an improved real time PCR for the detection of bovine leukemia provirus nucleic acid and its use in the clarification of inconclusive serological test results. J Virol Methods. 2013; 189(2):258-264. https:// doi.org/10.1016/j.jviromet.2013.02.014

30. Martin D, Arjona A, Soto I, Barquero N, Viana M, Gómez-Lucía E. Comparative study of PCR as a direct assay and ELISA and AGID as indirect assays for the detection of bovine leukaemia virus. J Vet Med B. 2001; 48(2):97-106. https:// doi.org/10.1111/j.1439-0450.2001.00424.x

31. Buzała E1, Dereń W. Comparison of PLA with AGID and ELISA results in serology diagnosis of bovine leukosis. Pol J Vet Sci. 2003; 6(3 Suppl):9-11.

32. Kozaczyńska B. Diagnostic value of different ELISA kits for the determination of antibodies against bovine leukemia virus (BLV). Bul Vet Inst Pulawy. 1999; 43(2):133-138. 
33. Jaworski JP, Pluta A, Rola-Łuszczak M, McGowan SL, Finnegan C, Heenemann K, et al. Interlaboratory Comparison of Six Real-Time PCR Assays for Detection of Bovine Leukemia Virus Proviral DNA. J Clin Microbiol. 2018; 56(7):e00304-18. https://doi.org/10.1128/ JCM.00304-18
34. Jaworski JP, Pluta A, Rola-Łuszczak M, McGowan SL, Finnegan C, Heenemann K, et al. Interlaboratory Comparison of Six Real-Time PCR Assays for Detection of Bovine Leukemia Virus Proviral DNA. J Clin Microbiol. 2018; 56(7):e00304-18.

Received 28.10.2020 